\title{
SURFACE CHLOROPHYLL-A VARIATIONS ALONG THE SOUTHERN COAST OF JAVA DURING TWO CONTRASTING INDIAN OCEAN DIPOLE EVENTS: 2015 AND 2016
}

\author{
NETTY KURNIAWATI ${ }^{1}$, QURNIA WULAN SARI ${ }^{1}$, RIZA YULIRATNO SETIAWAN ${ }^{2}$, EKO \\ SISWANTO $^{3}$, FAUZIYAH ${ }^{4}$, DEDI SETIABUDIDAYA ${ }^{1}$ AND ISKHAQ ISKANDAR*1 \\ ${ }^{1}$ Department of Physics, Faculty of Mathematics and Natural Sciences, University of Sriwijaya, Indralaya, Sumatera Selatan, \\ 30662, Indonesia. 2Department of Fisheries, Faculty of Agriculture, Universitas Gadjah Mada, Yogyakarta, Indonesia. \\ ${ }^{3}$ Japan Agency for Marine-Earth Science and Technology (JAMSTEC), 2-15 Natsushima-cho, Yokosuka-city, Kanagawa \\ 237-0061, Japan. ${ }^{4}$ Department of Marine Science, Faculty of Mathematics and Natural Sciences, University of Sriwijaya, \\ Indralaya, Sumatera Selatan, 30662, Indonesia.
}

*Corresponding author: iskhaq@mipa.unsri.ac.id

Submitted final draft: 1 July $2020 \quad$ Accepted: 18 July 2020

http://doi.org/10.46754/jssm.2021.04.010

\begin{abstract}
Satellite-derived surface chlorophyll-a (chl-a) concentration off the southern coast of Java during the southeast monsoon season (July-September) of 2015 positive Indian Ocean Dipole (IOD) and 2016 negative IOD events was analyzed. The analysis was intended to examine how strong was the coastal upwelling, indicated by Ekman transport, during those two contrasting IOD events affecting the surface chl-a distribution. The results, however, did not reveal robust contrast patterns as was expected. Only weak coastal upwelling signals (offshore Ekman transport) were observed during the 2015 positive IOD event. This weak offshore Ekman transport combined with positive atmospheric flux prevented the exchange of cold thermocline water with the surface, resulting in weak SST cooling. The surface chl-a also only showed sporadic anomalous blooming during 2015. On the other hand, the 2016 negative IOD event has robust atmospheric and oceanic patterns. Strong onshore Ekman transport and distinct positive SST anomalies were observed. The surface chl-a patterns showing negative anomalies also clearly marked the oceanic response to those anomalously strong onshore Ekman transport. The results marked the important role of coastal upwelling for surface chl-a bloom in this area.
\end{abstract}

Keywords: Chlorophyll-a; Ekman transport; Indian Ocean Dipole.

\section{Introduction}

The Southeastern Tropical Indian Ocean (SETIO) region experiences a strong impact from the seasonal monsoonal winds (Wyrtki, 1962). During the southeast monsoon season from July to September, upwelling favorable winds, namely the southeasterly winds, blow over the southern part of the Indonesian region, along the coasts of Sumatera and Java. These southeasterly winds generate offshore Ekman transport that causes upward motion of subsurface water. As a result, cold sea surface temperature (SST) is observed along the southern coast of Sumatera and Java. On the other hand, during the northwest monsoon season from December to February, the northeasterly winds blow along the southern coast of Sumatera and Java. These winds induce onshore Ekman transport that causes downwelling. As a result, the downward motion of the surface water warms SST along the southern coast of Sumatera and Java. In addition, the SETIO region also experiences remote wind forcing from the eastern equatorial Indian Ocean (EqIO) during the monsoon breaks in April/May and October/November (Iskandar et al., 2005; Iskandar et al., 2014; Wang, 2017). The westerly (easterly) winds along the EqIO generated downwelling (upwelling) Kelvin waves propagating eastward to reach the western coast of Sumatera. Once the waves reached the coast, they bifurcated to the south and to the north as coastal Kelvin waves propagating along the coastal wave-guide. The southward propagating coastal Kelvin waves will affect the oceanic condition in the SETIO region (Iskandar et al., 2014; Chen et al., 2015). Besides, some part of the energy of these equatorial Kelvin waves is 
reflected back into the interior Indian Ocean as a series of westward propagating Rossby waves.

The SETIO region also experienced interannual variations associated with coupled ocean-atmosphere phenomena, namely El NiñoSouthern Oscillation (ENSO) (Deni Okta Lestari et al., 2018) and the Indian Ocean Dipole (IOD) (Saji et al., 1999; Webster et al., 1999). Both phenomena had caused anomalously strong upwelling during the southeast monsoon season (Kok et al., 2019), leading to surface chlorophyll-a (chl-a) bloom in the SETIO (Susanto \& Marra, 2005; Iskandar, Sari, et al., 2017; Hendiarti et al., 2005; Handayani et al., 2019). In addition to the coastal upwelling, enhanced eddy activities during the positive IOD event had also induced offshore surface chl-a in the SETIO region (Iskandar et al., 2010).

While positive IOD events took place in the tropical Indian Ocean in 2015 (Liu et al., 2017; D.O. Lestari et al., 2018; Utari et al., 2018), strong negative IOD event was observed in 2016 (Iskandar et al., 2018; Lu et al., 2018). Both positive and negative IOD events typically developed in late boreal spring, matured in boreal summer, and terminated in boreal fall. Note that the positive IOD event is associated with anomalously strong southeasterly winds that induced anomalously strong upwelling. Meanwhile, the negative IOD event is characterized by anomalously strong northwesterly winds that enhanced strong downwelling along the southern coast of Sumatera and Java (Saji et al., 1999; Murtugudde et al., 2000).

Although extreme El Niño events took place in the tropical Pacific during 2015/2016, in this study, we only evaluated the possible impact of the 2015 positive IOD and 2016 negative IOD events on the surface chl-a distribution along the southern coast of Java. The focus of the analysis was on the spatial and temporal variability as well as the intensity variation of the coastal upwelling associated with those two contrasting IOD events. The analysis relied on the satellitedriven surface chl-a, SST, and the surface winds (Ekman transport).

\section{Materials and Methods}

The study area is located along the southern coast Java, which is well known as the IndoAustralian Basin (IAB) and it spans zonally from $102^{\circ} \mathrm{E}$ to $116^{\circ} \mathrm{E}$ and from $12^{\circ} \mathrm{S}$ to $4^{\circ} \mathrm{S}$ (Figure 1). This area is known as an intersection of water masses from the Pacific Ocean, the Indian Ocean, and the Indonesian Seas (Sprintall et al., 1999). A numerical study has shown that the Indonesian Throughflow (ITF) significantly supplied nutrient-rich water to the IAB area (Iskandar et al., 2010). Besides, the IAB also experiences strong seasonal modulation by the monsoonal winds, as well as interannual modulation by the Indo-Pacific climate modes (Susanto \& Marra 2005; Iskandar et al., 2009).

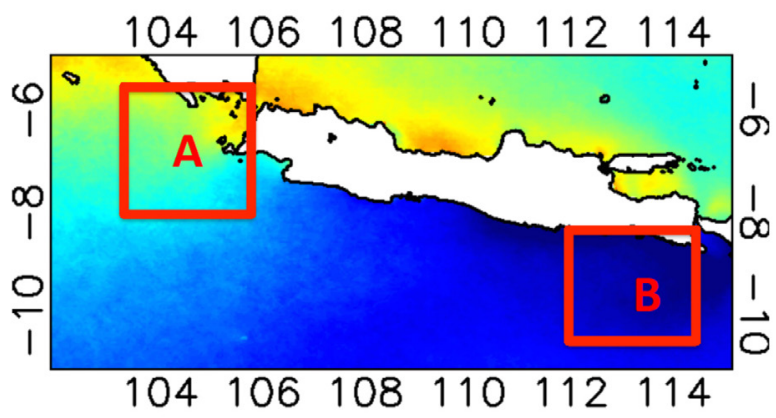

Figure 1: Study area along the southern coast of Sumatera and Java $\left(102^{\circ} \mathrm{E}-116^{\circ} \mathrm{E}, 12^{\circ} \mathrm{S}-4^{\circ} \mathrm{S}\right)$. The colors indicate a monthly mean of surface chlorophyll-a concentration (mg/m3) in August. Boxes A and B represent the western and eastern region for the calculation of spatial average of monthly climatology of surfcae chlorophyll-a, SST and surface wind stress 
In this study, daily surface chl-a and semi-daily SST Level-3 data were obtained from the Moderate Resolution Imaging Spectroradiometer (MODIS) provided by the National Aeronautics and Space Administration (NASA). The data have a uniform longitudinal and latitudinal resolutions of $0.04^{\circ}$ and cover a period of January 2003 to December 2017 (Esaias et al., 1998).

To evaluate the dynamical forcing underlying surface chl-a variation in this area, surface wind data obtained from the semi daily Quick Scatterometer (QuikSCAT) were used to calculate the Ekman transport (Ricciardulli $\&$ Wentz, 2015). The data cover a period from January 2003 to November 2009. These surface wind data were combined with that obtained from the Advanced Scatterometer (ASCAT) covering a period of December 2009 to December 2017 (Figa-Saldana et al., 2002). Both QuikSCAT and ASCAT data have a horizontal resolution of $0.25^{\circ}$. The Ekman transport was defined as (Gill, 1983):

$$
\begin{aligned}
& M_{x}=\int_{0}^{z} \rho u d z, \\
& M_{y}=\int_{0}^{z} \rho v d z,
\end{aligned}
$$

where $M_{\mathrm{x}}$ and $M_{\mathrm{y}}$ indicate the zonal and meridional Ekman transports, respectively. $\rho$ is the density of seawater. Note that the zonal $(u)$ and meridional $(v)$ currents were defined as:

$$
\begin{gathered}
u=\frac{1}{f \rho} \frac{\partial \tau_{y}}{\partial z}, \\
v=-\frac{1}{f \rho} \frac{\partial \tau_{x}}{\partial z},
\end{gathered}
$$

where $f$ represents the Coriolis force. Here, the wind stress $(\tau)$ was calculated as,

$$
\begin{gathered}
\tau_{x}=\rho_{a} C_{D}\left|\bar{U}_{10}\right| \bar{U}_{10}, \\
\tau_{y}=\rho_{a} C_{D}\left|\bar{V}_{10}\right| \bar{V}_{10},
\end{gathered}
$$

where $\rho_{\mathrm{a}}$ represents the air density $\left(1.25 \mathrm{~kg} \mathrm{~m}^{-3}\right)$, $C_{\mathrm{D}}$ is the drag coefficient $\left(2.6 \times 10^{-3}\right)$, and $U_{10}$ and
$V_{10}$ are the zonal and meridional winds at $10 \mathrm{~m}$ above the sea.

In this study, all data were averaged into monthly mean. The monthly anomaly was defined as the deviation from its monthly climatology. Note that the monthly climatology was calculated based on the monthly mean for the period of January 2003 to December 2017.

\section{Results and Discussion}

\section{Seasonal Variation}

To examine interannual variations of surface chl-a concentration along the southern coast of Java, we first evaluated its seasonal variation. Figure 2 shows the monthly variations of Ekman transport, SST, and surface chl-a during the southeast monsoon season (July-September). It is shown that strong offshore Ekman transport induced by strong southeasterly winds along the southern coast of Indonesia was observed during the southeast monsoon season (Figures 2a-c). This offshore Ekman transport indicates coastal upwelling along the southern coast of Java until the southwestern coast of Sumatera. Interestingly, the intensity of the coastal upwelling reveals spatial variation, in which the upwelling was strengthened as we moved westward. We found that the strongest upwelling intensity was in the southwest of the Sunda Strait.

The upwelling signals can be inferred from the observed SST as shown in Figures 2d-f. Low SST of up to $26^{\circ} \mathrm{C}$ covered the area of IAB in particular along the southern coast of Java. Interestingly, the SST in the Sunda Strait and the area west of Sumatera did not decrease as much as what was observed off South Java. Previous studies have shown that remote forcing from the equatorial Indian Ocean in terms of downwelling Kelvin waves induced warm surface water in this area during the southeast monsoon season (Iskandar et al., 2005; Chen et al., 2015). Meanwhile, a recent study has proposed that the outflow from the Java Sea to the Indian Ocean through the Sunda Strait has an important role in regulating SST there (Xu et al., 2018). Due to 
a) Ekman Transport - July

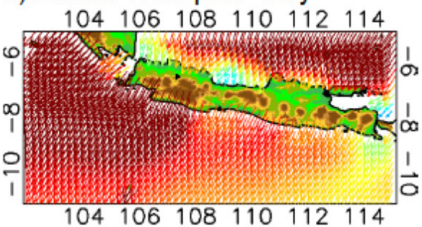

b) Ekman Transport - August $104106108 \quad 110112114$



104106108110112114

e) SST - August

d) SST - July

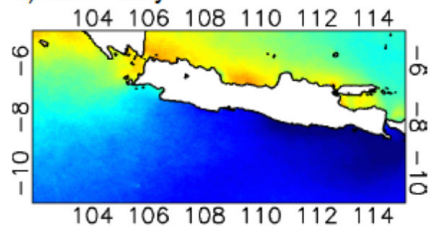

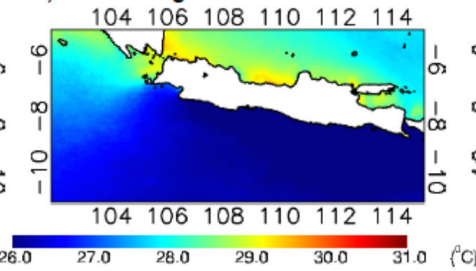

c) Ekman Transport - September $104106108 \quad 110112 \quad 114$

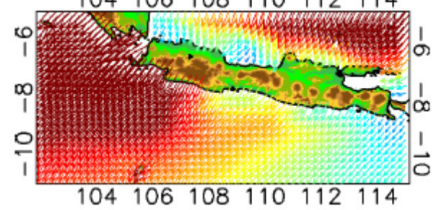

g) Chlorophyll a - July

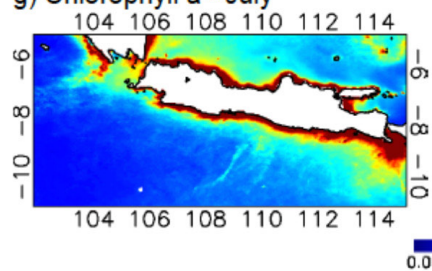

h) Chlorophyll a - August

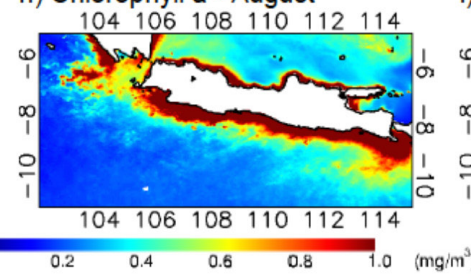

f) SST - September

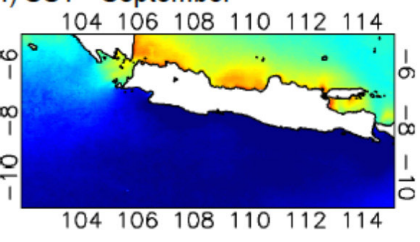

Figure 2: Monthly values of Ekman transport (upper panel), sea surface temperature (middle panel), and surface chlorophyll-a (lower panel) during July (left), August (middle), and September (right)

the sea level gradient between the southern and northern part of the Sunda Strait, warmer water mass from the Java Sea was transported to the Indian Ocean through the Sunda Strait during the southeast monsoon season.

Another indicator of the upwelling process is the surface chl-a concentration, which is shown in Figures 2g-i. During the southeast monsoon season, the coastal upwelling brings subsurface nutrient-rich water towards the surface, leading to high surface chl-a concentration. It is clearly shown that high surface chl-a concentration $(>0.8 \mathrm{mg} / \mathrm{m} 3)$ was observed along the southern coast of Java during the period of the upwelling season. Interestingly, very high surface chl-a concentration was colocated with the location of the strongest offshore Ekman transport (e.g. off southwestern Sumatera and the Sunda Strait) (Figures 2h-i). Therefore, we may suggest that nutrient-rich water from the Sunda Strait throughflow contributes to observed high surface chl-a concentration off the southwestern Sumatera and the Sunda Strait.

The situations are reversed during the northwest monsoon season from December to February (Figure 3). The northwesterly winds along the southern coast of Java generate onshore Ekman transport (Figures 3a-c). However, the intensity of the onshore Ekman transport during the northwest monsoon season is much weaker than the offshore Ekman transport observed during the southeast monsoon season. Nevertheless, as we found during the southeast monsoon, the intensity of onshore Ekman transport during the northwest monsoon also reveals spatial variations. Strong onshore Ekman transport was observed off the southwestern coast of Sumatera. In addition, we also found relatively strong onshore Ekman transport off South Central Java (Figures 3b-c). This onshore Ekman transports are associated with downwelling phenomena, indicated by 

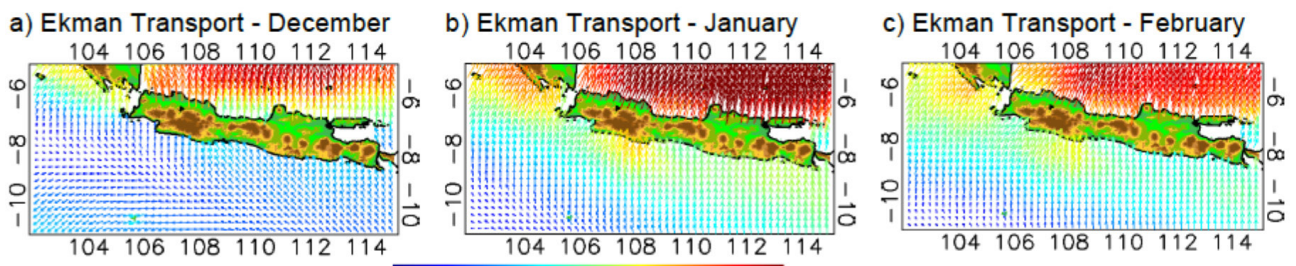

d) SST - December

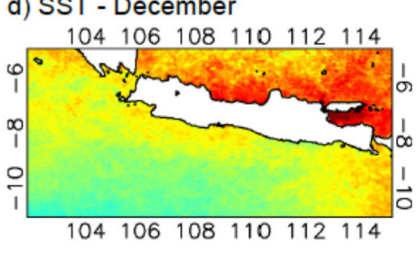

e) SST - January

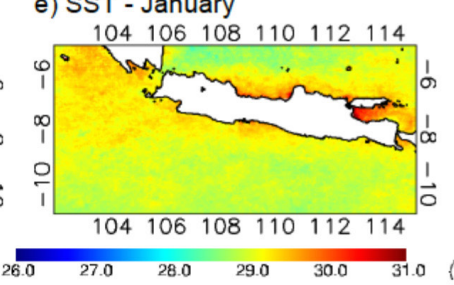

g) Chlorophyll a - December

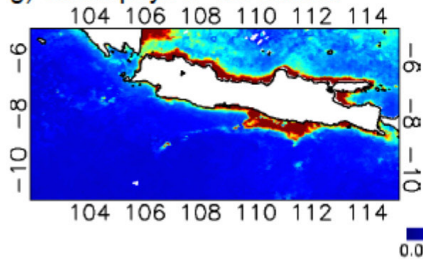

h) Chlorophyll a - January

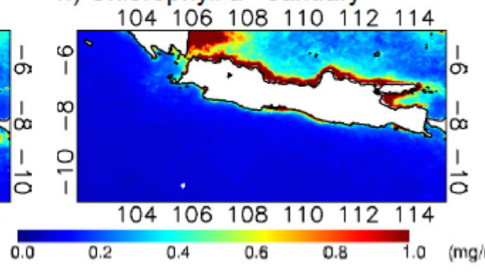

f) SST - February

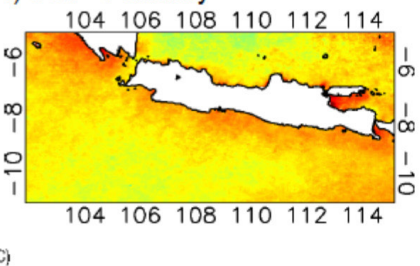

i) Chlorophyll a - February

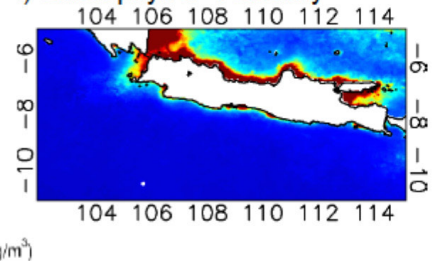

Figure 3: Monthly values of Ekman transport (upper panel), sea surface temperature (middle panel), and surface chlorophyll-a (lower panel) in December (left), January (middle), and February (right)

high SST of up to about $29.5^{\circ} \mathrm{C}$ observed off South Java (Figures 3d-f). The SST contrast between the southeast and northwest monsoon seasons marks a clear seasonal variation in this region. Note that during the northwest monsoon season the SST variability is primarily driven by the shortwave radiation as well as the variability of sensible heat flux associated with the wind speed (Chen et al., 2015). Another sign of the downwelling process is the low surface chl-a concentration observed off South Java (Figures $3 g-i)$. These surface chl-a patterns reveal a clear seasonal contrast between the southeast and northwest monsoon seasons.

In order to evaluate in more detail the spatio-temporal variability of surface chl-a, SST and surface wind stress, we calculated spatial averaged of those parameters over the western (box A) and eastern (box B) regions marked in Figure 1 (Setiawan et al., 2020). It is shown that the observed surface chl-a in the eastern region was higher than that observed in the western region (Figure 4a). In the eastern region, the surface chl-a concentration started to increase in May, which was one month earlier than that observed in the western region. Note that this increase of surface chl-a concentration was in phase with a sharp decrease in SST, both in the eastern and western regions (Figure 4b). The peak of surface chl-a bloom was observed in September both in the eastern and western regions, while the observed lowest SST has shown different timing. The lowest SST in the western basin was observed in phase with the peak of surface chl-a bloom, while that in the eastern basin was observed earlier than the peak of surface chl-a bloom (August). It is also interesting to note that the magnitude of observed lowest SST in the eastern basin was much lower $\left(24.9^{\circ} \mathrm{C}\right)$ compared to that observed in the western basin $\left(26.9^{\circ} \mathrm{C}\right)$. Previous studies have shown that surface chl-a variation in this region was very sensitive to the wind-forced upwelling (Susanto \& Marra, 2005; Iskandar et 
al., 2009). The observed surface chl-a bloom and lowest SST were preceded by strong upwelling favorable wind along the coast (Figure 4c). We found that the strongest wind forcing was observed one month earlier than the lowest SST in both eastern (July) and western (August) regions.

\section{Interannual Variation}

Previous studies have shown that during boreal summer/fall of 2015 and 2016, there were two contrasting IOD events took place in the tropical Indian Ocean (Utari et al., 2018; Deni Okta Lestari et al., 2018; Liu et al., 2017; Iskandar et al., 2018; Lu et al., 2018). Note that the 2015 positive IOD event was relatively weak as the tropical Indian Ocean experienced an impact from the unique central Pacific warming associated with the strong central Pacific El Niño in 2015 (Liu et al., 2017; Brainard et al., 2018; Xue \& Kumar, 2017). As a result, SST cooling

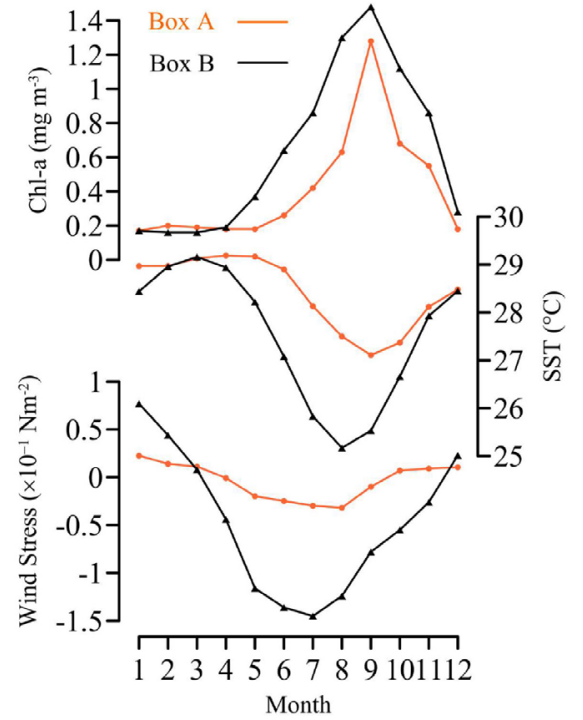

Figure 4: Time series of monthly climatology of surface chl-a (upper panel), SST (middle panel), and alongshore wind stress (lower panel) averaged over the western (box A) and eastern (box B) regions, the red boxes in Figure 1

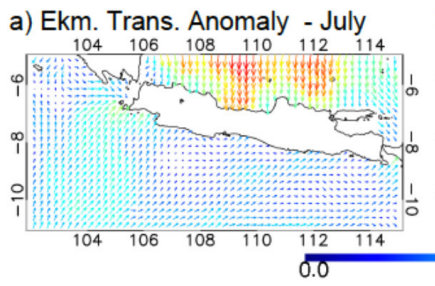

b) Ekm. Trans. Anomaly - August

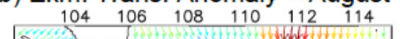

c) Ekm. Trans. Anomaly - Sept.

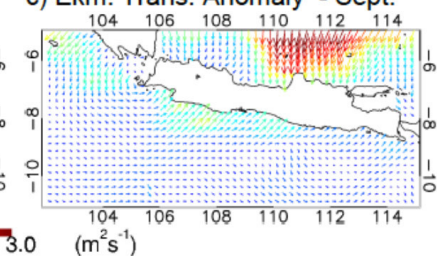

d) SST Anomaly - July

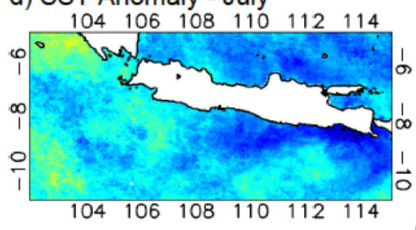

e) SST - Anomaly August

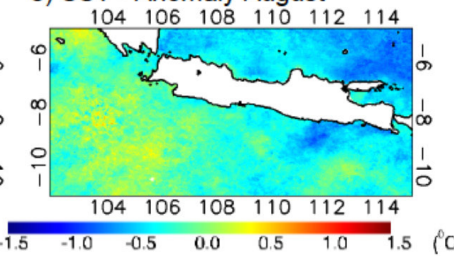

f) SST Anomaly - September

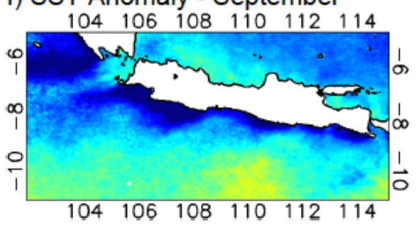

g) Chl a Anomaly - July

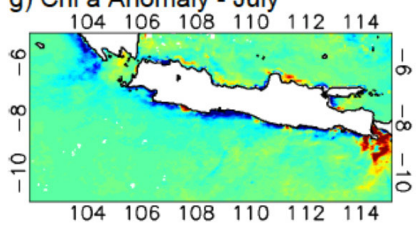

h) Chl a Anomaly - August

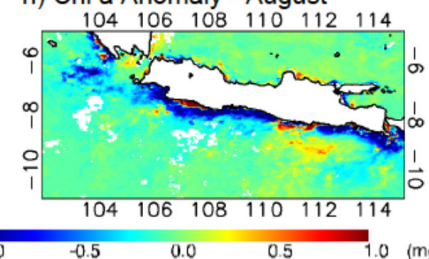

i) Chl a Anomaly - September

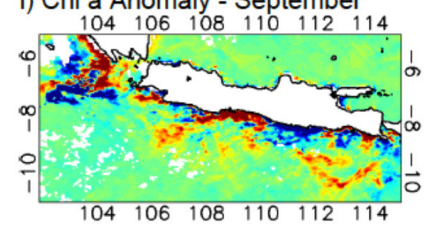

Figure 5: Monthly anomalies of Ekman transport (upper panel), sea surface temperature (middle panel), and surface chlorophyll-a (lower panel) during July (left), August (middle), and September (right) of 2015. Note that color in the upper panel indicates the magnitude of Ekman transport, positive (negative) values indicate the upwelling (downwelling) process 
in the southeastern tropical Indian Ocean was weaker compared to the typical positive IOD event following strong El Niño in 1997/98. Meanwhile, the negative IOD event in 2016 was qualified as one of the strongest negative IOD events on the record (Lu et al., 2018). In this section, we compare the oceanic responses to the anomalous atmospheric forces during the southeast monsoon seasons of 2015 and 2016.

Figure 5 shows the 2015 anomalies of the Ekman transport, SST, and surface chl-a concentration during July, August and September. It is interesting to note that anomalous strong offshore Ekman transport did not appear along the southern coast of Java as we expected for the positive IOD event (Figures 5a-c). Observed anomalous Ekman transport indicated spatial variation, both in magnitude and in direction. We found that the observed anomalous Ekman transport dominated by onshore direction indicated that only weak upwelling was observed during the 2015 positive IOD events. In July, there was anomalously onshore Ekman transport off south Sunda Strait (Figure 5a). However, anomalously strong offshore transport was observed northwest of the Sunda Strait in September, while the southern coast of Java indicated anomalous onshore transport (Figure $5 c)$.

As a result of these anomalously weak upwelling signals, distinct negative SST anomalies were not clearly present in the entire eastern pole during boreal summer of 2015 as we expected for the positive IOD (Figures 5d-f). In July, negative SST anomalies were observed in the south of Central to East Java and in the offshore area of southwest Sunda Strait (Figure $5 \mathrm{~d})$. The SST was getting warmer off south Java, except in the area of East Java in August (Figure 5e) before they got cooler again in September (Figure 5f). Note that the cooling and warming SST could not be attributed solely to the Ekman dynamics. A previous study has shown that the atmospheric flux played an important role in keeping the SST warm in the eastern tropical Indian Ocean during the 2015 positive IOD event (Utari et al., 2020). Also, the barrier layer was observed in the southeastern tropical Indian Ocean, where a relatively thicker barrier layer was observed off west Sumatra compared to that off south Java (Qu \& Meyers, 2005). The presence of the barrier layer may prevent the upward movement of cold water from the thermocline layer thus suppressing the impact of upwelling on the SST. A recent study has shown that during the peak phase of the 2015 positive IOD event the barrier layer was not present off South Java, while it was still observed off west Sumatera (Sari et al., 2020). Therefore, we may suggest that the SST still experienced significant cooling by a weak upwelling signal as the impact of upwelling was not shielded by the barrier layer off south Java.

Weak upwelling signal indicated by the patterns of anomalous Ekman transport and the SST anomalies along the southern coast of Java during the 2015 positive IOD had an impact on the surface chl-a distribution. Usually, we observed surface chl-a bloom during positive IOD events (Susanto \& Marra, 2005; Iskandar et al., 2009; Iskandar et al., 2010; Sari et al., 2020). However, during the 2015 positive IOD event, surface chl-a anomalies did not reveal significant bloom, rather they showed a negative surface chl-a anomalies along the coast during July and August (Figures 5g-h). Positive chl-a anomalies were observed offshore, in particular in the southern area of the East and Central Java. A previous study has shown that the offshore surface chl-a bloom was associated with enhanced cyclonic eddy activities during the positive IOD event (Iskandar et al., 2010). As the upwelling signals relatively got stronger in September, enhanced surface chl-a concentrations were also observed along the coast and in the offshore area (Figure 5i). Near the coast, strong positive chl-a concentrations were observed in the southwest of Sumatera and Sunda Strait, as well as along the southern coast of Central Java. It was clearly shown that the offshore chl-a bloom was co-located with negative SST anomalies, while anomalous negative chl-a concentration was co-located with positive SST anomalies (Figure 5i). 
It should be noted that from boreal summer of 2015 to boreal spring of 2016, super El Niño took place in the tropical Pacific (Liu et al., 2017; Xue \& Kumar, 2017; Iskandar et al., 2017; Kok et al., 2019). Earlier studies have reported a distinct surface chl-a bloom during the 1997/1998 El Niño event (Susanto \& Marra, 2005). Therefore, it may be concluded that the combined impacts of positive IOD and El Niño events have caused surface chl-a bloom during the boreal summer of 2015 .

On the other hand, in 2016 strong onshore Ekman transport was observed from the western coast of Sumatera to the southern coast of western Java in July-September 2016 as we expected for the negative IOD event (Figures 6a-c). Meanwhile, weak downwelling signal indicated by anomalously weak or even onshore Ekman transport was observed along the southern coast of Java from central to the eastern Java, with a strongest anomalously onshore Ekman transport observed in the eastern part. The oceanic response to this onshore Ekman transport was an increase in SST (positive anomaly) due to the downwelling event, in particular in the area south Java which shows a positive SST anomaly of up to $1.5^{\circ} \mathrm{C}$ (Figures $6 \mathrm{~d}-\mathrm{f}$ ). However, the SST off southwest Sunda Strait did not increase as high as that observed off south Java, although the strongest onshore Ekman transport was observed over this area. We propose that southward advection of relatively colder water from the Java Sea through the Sunda Strait may decrease the SST off southwest Sunda Strait (Figures 6d-f).

These robust observed downwelling events were reflected by anomalously low surface chl-a concentrations (Figures 6g-i). Strong negative surface chl-a anomalies were observed along the southern coast of Java as well as along the western coast of Sumatera during the whole southeastern monsoon season in 2016. Thus, a) Ekm. Trans. Anomaly - July

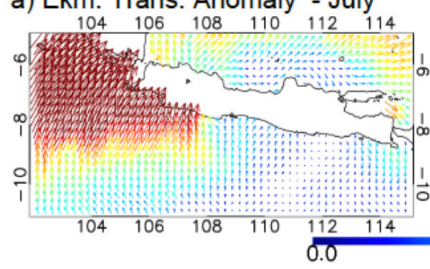

b) Ekm. Trans. Anomaly - August

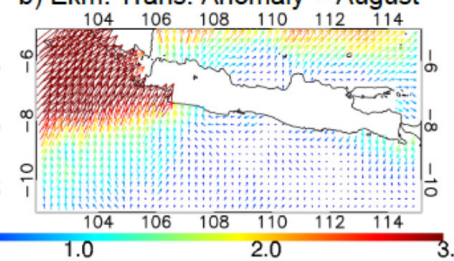

c) Ekm. Trans. Anomaly - Sept.

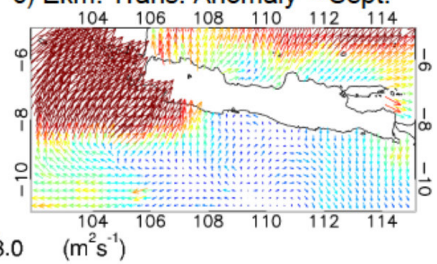

d) SST Anomaly - July

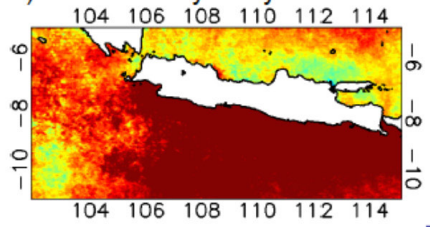

e) SST - Anomaly August

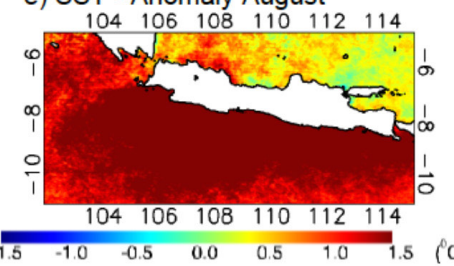

f) SST Anomaly - September

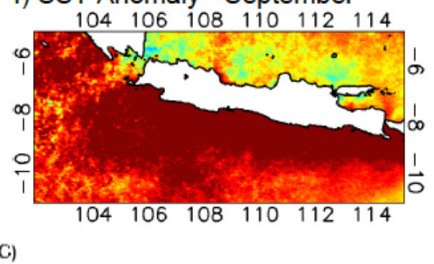

g) Chl a Anomaly - July

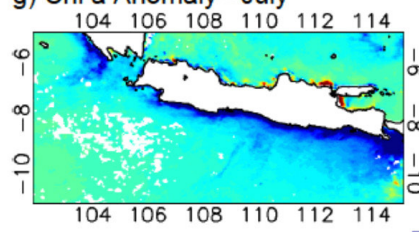

h) Chl a Anomaly - August

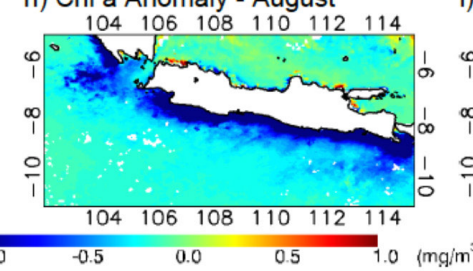

i) Chl a Anomaly - September

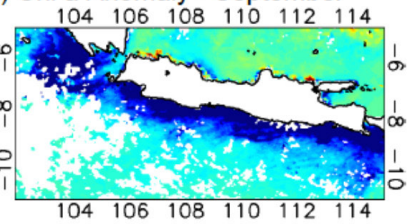

Figure 6: Monthly anomalies of Ekman transport (upper panel), sea surface temperature (middle panel), and surface chlorophyll-a (lower panel) during July (left), August (middle), and September (right) of 2016 
the contrast of that Ekman transport, SST and surface chl-a anomalies patterns between 2015 and 2016 clearly marked the interannual variations of surface chl-a concentration along the southern coast of Java associated with those two contrasting IOD events. Note that the 2015 positive IOD event was a unique event in which the southeastern tropical Indian Ocean did not experience extreme cooling as we expected for the positive IOD event. The SST gradient that creates a strong Dipole Mode Index (DMI) signal was coming from an anomalously strong warming event in the western tropical Indian Ocean (Utari et al., 2020). This is the reason why the SST and chl-a patterns did not show robust contrast patterns between the 2015 positive IOD and the 2016 negative IOD events. A previous study has reported that a weak La Niña Modoki was observed during 2016/2017 (Lestari et al., 2019). Its impact on the Indonesian region was much weaker compared to that of the 1998/1999 La Niña event (Asanuma et al., 2003; Susanto \& Marra, 2005). Therefore, we may conclude that the surface chl-a variability off south Java in 2016 was mainly associated with the negative IOD event.

\section{Conclusion}

In this study, daily MODIS surface chl-a and semi-daily $11-\mu \mathrm{m}$ SST Level-3, as well as combined surface wind data from QuikSCAT and ASCAT were used to investigate surface chl-a variations in the south of Java region in response to different atmospheric forces associated with two contrasting IOD events; positive event in 2015 and negative event in 2016. This study was designed to understand the surface chl-a variations during the upwelling season in two different IOD events. Note that during the southeast monsoon season (JulySeptember), the southeasterly winds and associated offshore Ekman transport play an important role in producing upwelling along the southern coast of Java and Sumatera, leading to increased surface chl-a concentration there. The situations are reversed during the northwest monsoon season (December-February).
Available observational data make it possible to examine how strong was the coastal upwelling during those two contrasting IOD events in 2015 and 2016. Our analysis indicated that anomalously strong coastal upwelling did not appear in 2015 as we expected for the positive IOD event. As a result, there were no distinct and continuous negative SST anomalies observed in the southern region of JavaSumatera during the peak phase of the event. Relatively weak offshore Ekman transport, combined with surface atmospheric flux, made the SST in the eastern pole remaining warm. The anomalous surface chl-a patterns also did not show a clear surface bloom as it was observed in other positive IOD events. It should be noted that an extremely strong El Niño event, so-called super El Niño, was observed in $2015 / 2016$. As previously reported, a strong El Niño could enhance surface chl-a bloom along the southern coast of Sumatera and Java (Susanto \& Marra, 2005). Therefore, we may conclude that the distinct surface chl-a bloom in 2015 was not solely driven by the positive IOD event. Contribution from the 2015/2016 super El Niño event to the surface chl-a was not neglected.

The situation was reversed during the 2016 negative IOD event. Anomalously strong onshore Ekman transport was observed from southwestern coast Sumatra to the western part of the Java coast. Relatively weaker onshore transport was observed from the central to the eastern Java coast. Robust positive SST anomalies were observed off south Java during the peak of 2016 negative IOD events. However, the SST anomalies did not show significant warming under the strongest onshore Ekman transport in the region off southwestern Sunda Strait. We suggest that the southward advection of cold water from the Java Sea has reduced the SST warming in that region. Meanwhile, the surface chl-a patterns indicated a distinct opposite pattern with those observed during the 2015 positive IOD event. Negative surface chl-a anomalies were observed throughout the 2016 negative IOD event. 


\section{Acknowledgements}

We thank two anonymous reviewers whose insights made the quality of this paper better. This study is supported by the University of Sriwijaya through the "Hibah Unggulan Profesi 2020”. E.S. and I.I. are supported by the Asia Pacific Network (APN) for Global Change Research through a research project for the Climate Adaptation Framework (CAF2016RR06-CMYSiswanto). Q.W.S and I.I. thank to ISEE, Nagoya University, Japan for supporting this work through the ISEE International Collaboration Project 2019/2020.

\section{References}

Asanuma, I., Matsumoto, K., Okano, H., Kawano, T., Hendiarti, N., \& Sachoemar, S. I. (2003). Spatial distribution of phytoplankton along the Sunda Islands: The monsoon anomaly in 1998. Journal of Geophysical Research Oceans, 108(C6), 33_1-33_14.

Brainard, R. E., Oliver, T., McPhaden, M. J., Cohen, A., Venegas, R., Heenan, A., Vargas-Ángel, B., Rotjan, R., Mangubhai, S., Flint, E., \& Hunter, S. A. (2018). Ecological Impacts of the 2015/16 El Niño in the Central Equatorial Pacific. Bulletin of the American Meteorological Society, 99(1), S21-S26.

Chen, G., Han, W., Li, Y., Wang, D., \& Shinoda, T. (2015). Intraseasonal variability of upwelling in the equatorial Eastern Indian Ocean. Journal of Geophysical Research: Oceans, 120(11), 7598-7615.

Esaias, W. E., Abbott, M. R., Barton, I., Brown, O. B., Campbell, J. W., Carder, K. L., Clark, D. K., Evans, R. H., Hoge, F. E., Gordon, H. R., Balch, W. M., Letelier, R., \& Minnett, P. J. (1998). An overview of MODIS capabilities for ocean science observations. IEEE Transactions on Geoscience and Remote Sensing, 36(4), 1250-1265.

Figa-Saldana, J., JJW, W., E, A., R, G., M R, G., $\&$ A, S. (2002). The advanced scatterometer
(ASCAT) on the meteorological operational (MetOp) platform: A follow on for European wind scatterometers. Canadian Journal of Remote Sensing, 28(3), 404-412.

Gill, A. E. (1983). Atmosphere-ocean dynamics, San Diego, California 92101-4495, USA: Academic Press.

Handayani, C., Soepardjo, A. H., \& Aldrian, E. (2019). Impact of a El-Nino Southern Oscillation (ENSO) to fluctuation of skipjack catch production in Southern East Java. Journal of Physics: Conference Series, 1217(1).

Hendiarti, N., Suwarso, Aldrian, E., Amri, K., Andiastuti, R., Sachoemar, S. I., \& Wahyono, I. B. (2005). Seasonal variation of pelagic fish catch around java. Oceanography, 18(SPL.ISS. 4), 114-123.

Iskandar, I., Lestari, D. O., Utari, P. A., Supardi, Rozirwan, Khakim, M. Y. N., Poerwono, P. \& Setiabudidaya, D. (2018). Evolution and impact of the 2016 negative Indian Ocean Dipole. Journal of Physics: Conference Series, 985(1).

Iskandar, I., Mardiansyah, W., Masumoto, Y., \& Yamagata, T. (2005). Intraseasonal Kelvin waves along the southern coast of Sumatra and Java. Journal of Geophysical Research C: Oceans, 110(4), 1-12.

Iskandar, I., Masumoto, Y., Mizuno, K., Sasaki, H., Affandi, A. K., Setiabudidaya, D., \& Syamsuddin, F. (2014). Coherent intraseasonal oceanic variations in the eastern equatorial Indian Ocean and in the Lombok and Ombai Straits from observations and a high-resolution OGCM. Journal of Geophysical Research: Oceans, 119(2).

Iskandar, I., Rao, S. A., \& Tozuka, T. (2009). Chlorophyll-a bloom along the southern coasts of Java and Sumatra during 2006. International Journal of Remote Sensing, 30(3), 663-671.

Iskandar, I., Rao, S. A., \& Tozuka, T. (2009). Chlorophyll-a bloom along the southern 
coasts of Java and Sumatra during 2006. International Journal of Remote Sensing, 30(3).

Iskandar, I., Sari, Q. W., Setiabudiday, D., Yustian, I., \& Monger, B. (2017). The distribution and variability of chlorophyll-a bloom in the southeastern tropical Indian ocean using empirical orthogonal function analysis. Biodiversitas, 18(4).

Iskandar, I., Sasaki, H., Sasai, Y., Masumoto, Y., \& Mizuno, K. (2010). A numerical investigation of eddy-induced chlorophyll bloom in the southeastern tropical Indian Ocean during Indian Ocean Dipole - 2006. Ocean Dynamics, 60(3), 731-742.

Iskandar, I., Utari, P. A., Lestari, D. O., Sari, Q. W., Setiabudidaya, D., Khakim, M. Y. N., Yustian, I., \& Dahlan, Z. (2017). Evolution of 2015/2016 El Niño and its impact on Indonesia. AIP Conference Proceedings, 1857(080001).

Kok, P. H., Akhir, M. F., \& Qiao, F. (2019). Distinctive characteristics of upwelling along the Peninsular Malaysia's east coast during 2009/10 and 2015/16 El Niños. Continental Shelf Research, 184(April), 1020.

Lestari, D. O., Sutriyono, E., Kadir, S., \& Iskandar, I. (2019). Impact of 2016 weak La Niña Modoki event over the Indonesian region. International Journal of GEOMATE, 17(61), 156-162.

Lestari, D. O., Sutriyono, E., Sabaruddin \& Iskandar, I. (2018). Severe drought event in Indonesia following 2015/16 El Niño/ positive Indian Dipole Events. Journal of Physics: Conference Series, 1011(1).

Lestari, D. O., Sutriyono, E., Sabaruddin, S., \& Iskandar, I. (2018). Respective influences of Indian Ocean Dipole and El Niño-Southern Oscillation on Indonesian precipitation. Journal of Mathematical and Fundamental Sciences, 50(3), 257-272.

Liu, L., Yang, G., Zhao, X., Feng, L., Han, G., Wu, Y., \& Yu, W. (2017). Why was the
Indian Ocean Dipole weak in the context of the extreme El Niño in 2015? Journal of Climate, 30(12), 4755-4761.

Lu, B., Ren, H. L., Scaife, A. A., Wu, J., Dunstone, N., Smith, D., Wan, J., Eade, R., MacLachlan, C., \& Gordon, M. (2018). An extreme negative Indian Ocean Dipole event in 2016: Dynamics and predictability. Climate Dynamics, 51(1-2), 89-100.

Murtugudde, R., McCreary, J. P., \& Busalacchi, A. J. (2000). Oceanic processes associated with anomalous events in the Indian Ocean with relevance to 1997-1998. Journal of Geophysical Research: Oceans, 105(C2), 3295-3306.

Qu, T., \& Meyers, G. (2005). Seasonal variation of barrier layer in the southeastern tropical Indian Ocean. Journal of Geophysical Research: Oceans, 110, 1-13.

Ricciardulli, L., \& Wentz, F. J. (2015). A scatterometer geophysical model function for climate-quality winds: QuikSCAT Ku2011. Journal of Atmospheric and Oceanic Technology, 32(10), 1829-1846.

Saji, N. H., Goswami, B. N., Vinayachandran, P. N., \& Yamagata, T. (1999). A dipole mode in the tropical Indian Ocean. Nature, 401(6751), 360-363.

Sari, Q. W., Utari, P. A., Setiabudidaya, D., Yustian, I., Siswanto, E., \& Iskandar, I. (2020). Surface chlorophyll-a variations in the Southeastern Tropical Indian Ocean during various types of the positive Indian Ocean Dipole events. International Journal of Remote Sensing, 41(1), 171-184.

Setiawan, R. Y., Wirasatriya, A., Hernawan, U., Leung, S., \& Iskandar, I. (2020). Spatio-temporal variability of surface chlorophyll-a in the Halmahera Sea and its relation to ENSO and the Indian Ocean Dipole. International Journal of Remote Sensing, 41(1), 284-299.

Sprintall, J., Chong, J., Syamsudin, F., Morawitz, W., Hautala, S., Bray, N., \& Wijffels, S. (1999). Dynamics of the South Java Current 
in the Indo-Australian Basin. Geophysical Research Letters, 26(16), 2493-2496.

Susanto, R. D., \& Marra, J. (2005). Effect of the 1997/98 El Niño on Chlorophyll a variability along the Southern Coasts of Java and Sumatra. Oceanography, 18(4), 124-127.

Utari, P. A., Khakim, M. Y. N., Setiabudidaya, D., \& Iskandar, I. (2019). Dynamics of 2015 positive Indian Ocean Dipole. Journal of Southern Hemisphere Earth Systems Science, 69(1), 75.

Utari, P. A., Nurkhakim, M. Y., Setiabudidaya, D., \& Iskandar, I. (2018). Response of near-surface currents in the Indian Ocean to the anomalous atmospheric condition in 2015. IOP Conference Series: Earth and Environmental Science, 149(1).

Wang, J. (2017). Observational bifurcation of Wyrtki Jets and its influence on the salinity balance in the eastern Indian Ocean. Atmospheric and Oceanic Science Letters, 2834(January), 1-8.
Webster, P. J., Moore, A., Loschnigg, J. P., \& Leben, R. R. (1999). Coupled oceanatmosphere dynamics in the Indian Ocean during 1997-98. Nature, 401(6751), 356360 .

Wyrtki, K. (1962). The upwelling in the region between java and Australia during the southeast monsoon. Marine and Freshwater Research, 13(3), 217-225.

Xu, T., Li, S., Hamzah, F., Setiawan, A., Susanto, R. D., Cao, G., \& Wei, Z. (2018). Intraseasonal flow and its impact on the chlorophyll-a concentration in the Sunda Strait and its vicinity. Deep Sea Research Part I: Oceanographic Research Papers, 136, 84-90.

Xue, Y., \& Kumar, A. (2017). Evolution of the 2015/16 El Niño and historical perspective since 1979. Science China Earth Sciences, 60(9), 1572-1588. 